\title{
CAFÉ RETRÔ: INVOCANDO UMA VOLTA AO PASSADO EM UM CENÁRIO MERCADOLÓGICO COMTEMPORÂNEO
}

\author{
Giovanna Vivian Goulart Palma ${ }^{1}$ \\ Vânia Braz de Oliveira ${ }^{2}$
}

Resumo: Este artigo traz um recorte sobre a sociedade e o indivíduo contemporâneo, onde os bens de consumo refletem o intangível e a nostalgia como uma necessidade do consumidor. O termo "retrô" é acionado com frequência em uma sociedade que se alimenta das ilimitadas possibilidades de consumo nostálgico oferecido pela tecnologia. O passado se porta como detentor de um significado emocional, já que o antigo ilustra os desejos presentes do consumidor. Novas oportunidades mercadológicas, evocando outras épocas, focam valores e emoções sanando desejos e necessidade reais no consumidor contemporâneo. Frente a este cenário torna-se possivel a criação de uma marca com características estéticas retrô, mas que dialogue com um consumidor contemporâneo, disposto a consumir um produto tradicional como o café em um cenário que o remeta ao passado, sem se distanciar da contemporaneidade. Palavras-chave: Consumidor; Contemporâneo; Retrô; Café; Consumo.

\footnotetext{
1 Jornalismo/Universidade do Vale do Paraíba, Brasil. E-mail: giovannavgoulartp@gmail.com.

2 Jornalismo/Universidade do Vale do Paraíba, Brasil. E-mail: vaniajor@univap.br.
} 